\title{
Concordia Apostolorum - Concordia Augustorum. Building a Corporate Image for the Theodosian Dynasty
}

\author{
Gitte Lønstrup Dal Santo
}

"His faith in the apostles of Christ, he displayed in the following manner. First he built a church of Peter and Paul, which had not previously existed in Byzantium". Thus wrote Procopius in his Buildings, a panegyric he dedicated to the Emperor Justinian I $(527-565)$ at some point during the $55^{0 s} .^{2}$ He refers to the church Justinian constructed in honour of Sts. Peter and Paul adjacent to the imperial palace in Constantinople. And he makes a significant claim: that this church of Justinian's was the first in Constantinople ever to have been dedicated to these apostles. It seems, however, that Procopius was misled about Justinian's church. The cult of Peter and Paul was not new in Justinian's time. In fact, the cult of these two apostles, customarily associated with the city of Rome on the Tiber, was already well established in the religious and devotional lives of the Christian inhabitants of the New Rome on the Bosporus. ${ }^{3}$ During the fifth century, various churches honouring the two apostles were built in and around Constantinople.

This paper will focus on the late fourth-century origins of the Constantinopolitan cult of Sts. Peter and Paul as well two fifth-century churches, arguing that the cult and the designated church buildings were important elements in the making of what Malcolm Errington has called the "corporate image" of the Theodosian dynasty. ${ }^{4}$ Along with law codes and marriage contracts, images

1 Procopius Buildings 1.4.1, ed. Henry Bronson Dewing (Cambridge, Mass., 1940, 2002), p. 43.

2 Averil Cameron dates Buildings to c. 554 while Peter Sarris argues for a date after the collapse of the dome of Hagia Sophia in 558, to which he suggests there are hidden references in the text. See Averil Cameron, Procopius and the sixth century (London, 1985), p. 85; Peter Sarris, The Secret History (London 2007), p. xx.

3 I have discussed the Constantinopolitan cult of Peter and Paul at length in my PhD dissertation Concordia Apostolorum - Concordia Augustorum. The making of shared memory in and between the two Romes in the fourth and fifth century (discussed at Aarhus University, October 2010). See also Gitte Lønstrup Dal Santo, "Bishop and Believers - Patrons and Viewers: Appropriating the Roman Patrons Saints Peter and Paul in Constantinople," in Patrons and Viewers in Late Antiquity, eds. Stine Birk and Birte Poulsen (Aarhus 2012), pp. 237-257.

4 Malcolm Errington, Roman Imperial Policy from Julian to Theodosius (Chapel Hill, 2006), p. 166.

(C) GITTE LøNSTRUP DAL SANTO, 2015 | DOI 10.1163/9789004291935_008

This is an open access chapter distributed under the terms of the Creative Commons AttributionNoncommercial 3.0 Unported (CC-BY-NC 3.0) License. 
and numismatic legends, the cult of the two leading apostles reinforced ideologies of unity-of-empire and Roman-ness that were central to the way in which the Theodosian dynasty represented itself. As we shall see, dynastic patronage of a church to Peter and Paul in Constantinople manifested the desire of the Theodosian house to bind together both church and empire and the two branches of the dynasty, the one in the east and the other in the west, through an ideal of concordia (concord, unity, harmony, agreement) embodied in the iconography of Sts. Peter and Paul, Roman saints par excellence.

The dynasty's desire to establish and maintain such unity must be understood in the context of the ecclesiastical conflicts, the foundation of other imperial residences such as Constantinople, which challenged Rome's leading position in the empire, and the Gothic and Vandal invasions that threatened the empire's survival, which characterised the late fourth century. From his accession in 379, Theodosius I promoted an image of unity between church and empire and between the various groups of people within them. The early reigns of his young sons, Arcadius and Honorius, however, were marked by the rivalry of their guardians, Flavius Rufinus ( $†$ 395) and Flavius Stilicho ( $†$ 408). A certain division between the eastern and western halves of the Theodosian dynasty followed the death of Theodosius I in January 395, even if rupture did not endanger the idea of the Roman empire as a single entity. As pointed out by Hervé Inglebert earlier in this volume: "les discordes étaient unitaires". Indeed, the accession of Theodosius' grandson, Theodosius II, saw a more stable period of consolidation in which the members of this imperial house engaged in and collaborated on a range of activities, among them church building.

\section{The Earliest Constantinopolitan Cult of Peter and Paul}

The cult of Peter and Paul seems to have been imported to Constantinople under Theodosius I. During a stay at Rome in 389 Theodosius was accompanied by his eastern praetorian prefect, Flavius Rufinus (future guardian of Arcadius). ${ }^{6}$ It is likely to have been on this trip that Rufinus obtained the relics

5 For an elaboration of Inglebert's themes, unicité, unite and unification, see p. 23 and p. 115 respectively.

6 The Prosopography of the later Roman Empire (PLRE), eds. A.H.M. Jones, J.R. Martindale and J. Morris (Cambridge, Eng., 1971-), 1, pp. 778-781: Rufinus was Praefectus Praetorius Orientis from 392 to 395, consul in 392 with Arcadius and magister officiorum of Theodosius in 388-392. See also Jean Pargoire, "Rufinianes," Byzantinische Zeitschrift 8 (1899), pp. 433-37 and "Les homélies de S. Jean Chrysostome en juillet 399," Echos d'Orient 3 (1900), p. 156. According to Pargoire, the sanctuary at Rufinianae was inaugurated in 393 or 394, which would have coin- 
of Sts. Peter and Paul, in whose honour Rufinus, on his return to the east, founded a palace, a mausoleum and a monastic complex across the strait from Constantinople. The relics were placed in a shrine there, designated as martyrion and apostoleion. In his ecclesiastical history from the mid-fifth century, Sozomen describes the site as bearing the name of Rufinus, Rufinianae, who erected a magnificent palace here and a great church in honour of the apostles, Peter and Paul, which he named Apostolium. ${ }^{7}$

Rufinus' church was the first centre of devotion to Peter and Paul within reach of Constantinople's Christian inhabitants. The prominence of this shrine is reflected in a sermon by John Chrysostom, bishop of Constantinople, in July 399 - only four years after Rufinus' assassination on 27 November, 395 by Gainas' Gothic mercenaries on Stilicho's orders. The proximity in time of this macabre event indicates that the site (which had become imperial property) had not suffered damnation with its founder. In the sermon, John Chrysostom describes how a few days earlier, he and his congregation crossed the strait to celebrate the feast of Peter and Paul:

Three days ago rain and heavy showers broke, and swept away everything $[\ldots]$. There were litanies and prayers of intercession, and our entire city went like a torrent to the places of the apostles, and took as their advocates Saint Peter and blessed Andrew, the pair of apostles, Paul and Timothy. After that, when God's anger was placated, crossing the sea, daring the waves, we went to Peter, the fundament of the faith, and Paul, the vessel of choice, and celebrated a spiritual festival. ${ }^{8}$

It is impossible to say much about the people who journeyed with Chrysostom from The Church of the Holy Apostles in Constantinople proper - a city which possessed the relics of Andrew and Timothy, whom Chrysostom describes as Peter and Paul's 'deputies' - to the martyrion known as Rufinianae, across the strait. All the same, it is clear that a group of people venerated Peter and Paul in Constantinople at this time. As a number of late-fourth and early-fifth

cided with a council held in Constantinople on 24 September 394. See also Alan Thacker "Rome of the martyrs: Saints, Cults and Relics, Fourth to Seventh centuries," in Roma Felix Formation and Reflections of Medieval Rome, eds. Éamonn Ó Carragáin and Carol Neuman de Vegvar (Aldershot, 2007), p. 41; John Matthews, Western Aristocracies and Imperial Court A.D. 364-425 (Oxford, 1990), pp. 134-136 and 227-228.

7 Sozomen, Historia Ecclesiastica 8.17, ed. Joseph Bidez (Berlin, 1960), pp. 370-371.

8 John Chrysostom, Contra ludos et theatra, ed. Patrologia Graeca 56, pp. 263-270. English translation in Wendy Mayer and Pauline Allen, John Chrysostom, The Early Church Fathers (London, 2000), p. 120. 
century sarcophagi excavated in Constantinople show, some also chose these apostles as their patrons in death. ${ }^{9}$ These sarcophagi, Rufinus' martyrion, Chrysostom's sermon and Sozomen's comment all provide significant evidence for a flourishing cult of Peter and Paul on the Bosphorus at the end of the fourth century.

What is more, John's sermon of July 399 demonstrates that the Feast of Peter and Paul was celebrated at Constantinople on June 29, in accordance with the long established tradition of the Church of Rome on the Tiber. In other words, the Church of the 'New Rome' observed in this instance, at least, the Roman festival calendar as opposed to that of other eastern churches such as Antioch, Jerusalem and Nicomedia, where the Feast of Peter and Paul was celebrated on December $28 .^{10}$ Indeed, the broader cultural setting of the cult of Peter and Paul in the New Rome seems closely connected to the ideas that had built up around the cult of these apostles in the Old Rome. ${ }^{11}$ For this reason, the next section will provide a brief overview of the cult of Peter and Paul at Rome, before proceeding to the first church dedicated to these apostles within the walls of Constantinople.

\section{Rome and Romanitas - Damasus and Concordia - Peter and Paul}

The controversial pontificate of Damasus in the late-fourth century represents an important milestone in the development of the Roman cult of Peter and Paul. Damasus consistently promoted the two apostles as emblems of unity within the Roman Church, encouraging the proliferation of the iconographical type known as the concordia apostolorum, an image of Peter and Paul facing each other as if to demonstrate agreement and inseparability (fig. 6.1). As Charles Pietri and John Huskinson have long since demonstrated, the Christian notion of concordia apostolorum appropriated an established ideology and iconography, those of concordia augustorum - unity between emperors that had been frequently stamped on Roman coins since the second century

9 The most prominent of these is the so-called Sarigüzel sarcophagus. See Gitte Lønstrup Dal Santo, "Bishop and Believers", pp. 250-254.

$10 \quad$ Hans Lietzmann, Die drei ältesten Martyrologien (Bonn, 1911), p. 12.

11 Chrysostom's acknowledgement and admiration of Peter and Paul as Roman patron saints is also reflected in his homily to Romans (In Epist ad Rom. Homil 32.4). On Chrysostom and unity, homonoia, within the church, see discussion in Nathaneal Andrade, "The Processions of John Chrysostom and the Contested Spaces of Constantinople," Journal of Early Christian Studies 18.2 (2010), pp. 180-181. 


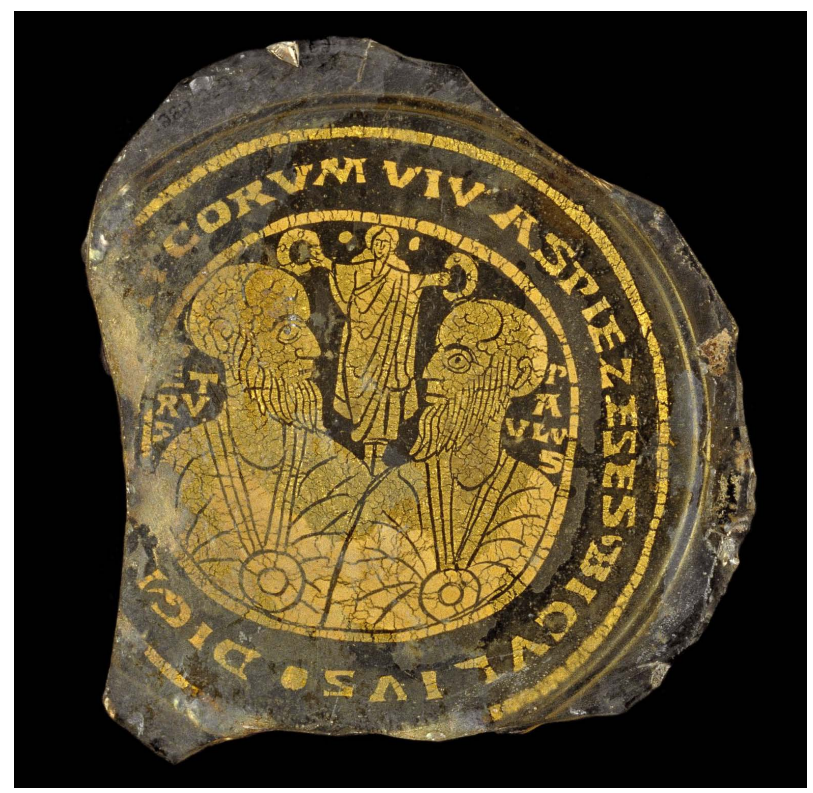

FIGURE 6.1

Fourth-century gold glass

(drinking vessel or bowl) featuring Peter and Paul, whose names are inscribed above and behind their heads around the border of the glass. They are depicted side by side, their faces turned towards each other as the Christian counterpart to the secular iconography of two emperors in Concordia. PHOTO (C) TRUSTEES OF THE BRITISH MUSEUM.

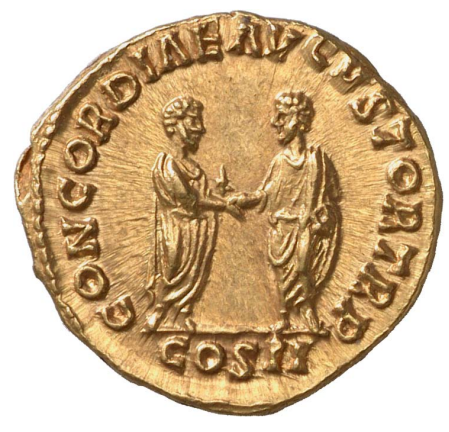

FIGURE 6.2

Concordia Augustorum. The reverse of a golden coin from 161 AD showing Emperors Marcus Aurelius and Lucius Verus shaking hands in a sign of concord. The inscription reads CONCORDIAE AVGVSTOR. This is one of the earliest Roman issues of a type that would continue to be minted for centuries. PHOTO (C) MÜNZKABINETT DER STAATLICHEN MUSEEN ZU BERLIN, 18200695. PHOTO BY LUTZ-JÜRGEN LÜBKE.

(fig. 6.2). ${ }^{12}$ Hence, Damasus used the image of Peter and Paul as a Christian counterpart to the imperial iconography as a way of shaping the ideal and ideology of Christian concord. Secular and ecclesiastical programmes were equally value-laden. This Christian image was widely diffused at the time on golden glasses and bronze medallions imprinted with the faces of the two apostles,

12 Charles Pietri, "Concordia Apostolorum et Renovatio Urbis. Culte des martyrs et propagande pontificale," Mélanges de l'Ecole française de Rome. Antiquité 73 (1961), 275-322; John M. Huskinson, Concordia Apostolorum: Christian Propaganda at Rome in the Fourth and Fifth Centuries: A Study in Early Christian Iconography and Iconology, BAR International Series (Oxford, 1982). 
which are likely to have been distributed or sold during the annual feast on June 29 attended by locals and visitors alike. ${ }^{13}$

When Damasus erected an epigram to Peter and Paul at their joint place of worship, the so-called memoria apostolorum on the Via Appia, the veneration of the two apostles together - and by extension the notion of their concordia - was again front and centre. ${ }^{14}$ Emphasising the essential duality of the cult, the inscription read:

\section{You should know that two saints used to dwell here Their names which you seek are Peter and Paul [...] \\ [Rome] This city was far more deserving than any other city of claiming the two apostles for its honorary citizens \\ Damasus here conveys your praises to the new stars. ${ }^{15}$}

With this epigram, Damasus consolidated the joint cult of Peter and Paul, which had existed at this site since the mid-third century as more than six hundred grafitti show. ${ }^{16}$ His emphasis on apostolic unity must be understood as a response to current needs and necessities. On a local scale, Damasus made an effort to gather competing schismatic groups in Rome within a unified church under his own authority. This hope for unity was reflected in the concord of the apostles, one which, significantly, was only achieved after their initial disagreements at apostolic meetings in Jerusalem and Antioch (Gal. 2:11-14). On a larger scale, Damasus' aim was to defend the sovereign primacy

13 Charles Pietri, Roma christiana: Recherches sur l'église de Rome, son organisation, sa politique, son idéologie de Miltiade à Sixte III 311-440 (Rome, 1976), p. 1540.

14 Damasus also raised the question of concord and discord within the church in other epigrams in nearby catacombs, such as the one decorating the tomb of St Eusebius in San Callixtus. See Antonio Ferrua, Epigrammata Damasiana (The Vatican City, 1942), ${ }^{\circ} 18$.

15 HIC HABITASSE/HABITARE PRIUS SANCTOS COGNOSCERE DEBES / NOMINA QUISQ. PETRI PARITER PAULIQUE REQUIRIS [...] / ROMA SUOS POTIUS MERUIT DEFENDERE CIVES / HAEC DAMASUs VESTRAS REFERAT NOVA SIDERA LAUDES. See Giovanni Battista De Rossi, Inscriptiones Christianae Urbis Romae septimo saecula antiquores, henceforth ICUR (Rome, 1857-1915) 5, 13273, and Antonio Ferrua, Epigrammata Damasiana, $\mathrm{n}^{\circ}{ }_{20}$. English translation by Dennis E. Trout, "Damasus and the Invention of Early Christian Rome," Journal of Medieval and Early Modern Studies 33 (2003), p. 532 note 38. Although the inscription is no longer extant, the text is known from early medieval itineraries, among them the eighth- or ninth-century Itinerarium Einsiedlense (ICUR 2. 1).

16 On the grafitti discovered on March 16, 1915, see Antonio Ferrua, "Rileggendo i graffiti di San Sebastiano," Civiltà Cattolica 3 (1956), 428-437 and 4, pp. 134-141. 
of the Roman church based on its foundation by Peter and Paul. By claiming, as he did in the inscription at the memoria apostolorum, that the apostles were citizens of Rome despite their eastern origins, Damasus underlined the preeminence of the city and its patron saints. Thus, he became crucial for defining the concept of Christian romanitas or Roman-ness, embodied in the image of the two apostles along with the notion of concord. ${ }^{17}$

\section{Theodosian Patronage at Rome and Ravenna}

It appears as if the Theodosian House bought into Damasus ideas of Christian concordia and romanitas, inasmuch as both ideologies served their own interests. Certainly, Theodosius I's Cunctos Populos edict of 380 aimed at creating unity within the church and thus within the empire. The edict forbade all heresies and expressly defined the orthodox faith as the faith of the Church of Rome with Damasus as its representative. Theodosius I and his co-emperors, Valentinian II and Gratian, matched these words with deeds, sponsoring the construction of the monumental St. Paul's Basilica on Rome's Via Ostiense. ${ }^{18}$ The lavish building became the equivalent to the grandiose basilica of St. Peter recently inaugurated at the Vatican. Moreover, the emperors connected these

17 While definitions of romanitas vary, the term is used here to denote Roman-ness: in particular, the power of being Roman and how that identity was combined with additional identities like 'Christian' and 'Constantinopolitan'. With respect to Constantinople, the Roman-ness of the city was defined by Roman institutions such as the Senate and prototypical elements of urban texture like the circus and the forum.

The construction of the basilica was undertaken by the Emperors Theodosius I, Valentinian II and Gratian. It began around $383-84$ or 386 , but Damasus ( $† 384$ ) and Gratian ( $†$ 383 ) both died either shortly after or possibly even before. The basilica was consecrated by Damasus' successor Siricius (384-399) in 390 during the reigns of Valentinian II in the west (375-392) and Theodosius I (379-395) in the east, and completed in 395 during the reign of Theodosius' sons Arcadius (395-408) and Honorius (395-423). For the rescript of 384 from Sallustius to Theodosius I, Valentinian II, and Arcadius, see John Curran, Pagan city and Christian capital: Rome in the fourth century (New York, 2000), p. 146-147. See also Thacker, "Rome of the martyrs", p. 31; Bryan Ward-Perkins, From Classical Antiquity to the Middle Ages. Urban Public Building in Northern and Central Italy AD 300-850 (Oxford, 1984), p. 237. The basilica is not mentioned in Damasus' or Siricius' vitae in the Liber Pontificalis, but the attribution to Siricius is documented in Collectio Avellana and in the inscription on a column in the portico outside the northern side of transept. See Marina Docci, San Paolo fuori le mura: dalle origini alla basilica delle "origini" (Rome, 2006), pp. 29-33; Giorgio Filippi, "La Basilica di San Paolo fuori le mura," in Pietro e Paolo. La storia, il culto, la memoria nei primi secoli, ed. Angela Donati (Milan, 200o), p. 59. 


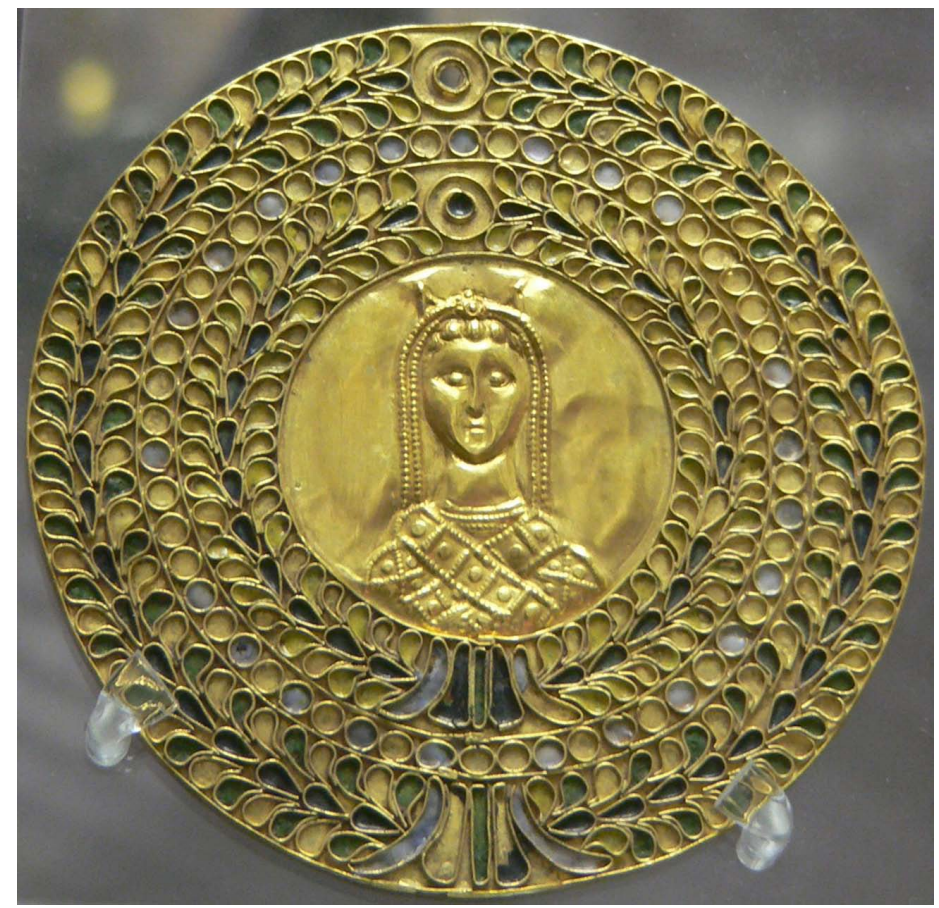

FIGURE 6.3 Fifth-century enamel and gold-leaf medallion depicting Licinia Eudoxia, daughter of Theodosius II and wife of Valentinian III - entrusted with the role of bridging the eastern and western halves of the dynasty. PHOTO (C DÉPARTEMENT DES MONNAIES, MÉDAILLES ET ANTIQUES, BIBLIOTHÈQUE NATIONALE DE FRANCE, INV. M. 1688.

prestigious burial basilicas housing the believed tombs or memoriae of Peter and Paul with processional roads and arches. ${ }^{19}$

Patronage of Sts. Peter and Paul seems to have become a Leitmotif of the Theodosian dynasty. A dedicatory inscription from the Titulus Apostolorum at Rome (now S. Pietro in Vincoli) shows that Theodosius II sponsored the reconstruction of this church and its contemporary rededication to Sts. Peter and Paul by Sixtus III around 439: THEODOSIUS PATER EUDOCIA CUM CONIUGE VOTUM CUMQUE SUO SUPPLEX EUDOXIA NOMINE SOLVIT (Theodosius, the father, together with his wife Eudocia and with Eudoxia, in her own name, humbly fulfilled the vow). ${ }^{20}$ The inscription names Theodosius II's daughter (fig. 6.3),

19 Margarete Steinby ed., Lexicon Topographicum Urbis Romae 1 (Rome, 1993-200o), p. 96 and 5 , p. 147.

20 ICUR 2, pp. 110, 66; Richard Krautheimer, Corpus Basilicarum Christianorum Romae 3 (The Vatican City, 1937-77), p. 181. I am grateful to Marianne Pade for discussing the English translation of the inscription. 
Licinia Eudoxia (422-462) and describes her involvement in the project as the execution of a vow of sponsorship made by her mother and father. Owing to the patronage of this empress, the church came to be unofficially known as titulus eudoxiae. ${ }^{21}$

Earlier in the 430s Licinia Eudoxia had fulfilled another vow made on her behalf by her father in 424 , when she, as a girl of two or three years of age, was betrothed to her cousin, the Western Emperor, Valentinian III. The pair was married in Constantinople on October $29,437 .{ }^{22}$ Such marriage contracts had precedents within the dynasty: Theodosius I, for example, married Galla of the house of Valentinian II in $387 .{ }^{23}$ To commemorate the engagement of 424 , the wedding in 437, the crowning of Valentinian III and the shared consulship of Theodosius and Valentinian between 425 and 426 , the imperial mints struck gold solidi that proclaimed the collaboration, connection and unity between the two halves of the Theodosian House embodied in the two emperors. The SALUS REI PUBLICAE legend that appeared on many of these coins is closely linked to the notion of concordia augustorum in as much as salus, public safety, was the desired outcome of unity within the empire. Interestingly, the coins issued under Theodosius II, invoking the rhetoric of concord, outnumber those of Honorius in the ratio of about five to two. ${ }^{24}$

On the special FELICITER NUPTIIS solidi from 437 (fig 6.4-5), the senior emperor Theodosius II is shown embracing the bride (Licinia Eudoxia) and groom (Valentinian III). As the image sought to convey, the wedding was a clear indication of the importance of exchanging gestures of concord between the eastern and western emperors of the Theodosian dynasty. As part of these nuptial festivities, Theodosius II also published the famous compilation of laws, Codex Theodosianus, which was intended to apply in both parts of the empire. The code was despatched with the imperial entourage that escorted the young couple west after the wedding and presented to the Senate upon the imperial couple's arrival at Rome on December 25, 438.25

The first documentation of this informal epithet (which continued until 959) is a letter written by Gregory the Great (c. 6oo) mentioning two presbyters from the titulus eudoxiae (Epist I, 366). See Richard Krautheimer, Corpus Basilicarum, 3, p. 182. lin, 1995), p. 393 and The Chronicle of Marcellinus Comes under the year 437, ed. Brian Croke (Sydney, 1995), p. 16.

Walter E. Kaegi, Byzantium and the decline of Rome (Princeton, 1968), pp. 20-25.

24 John P.C. Kent, The Divided Empire and the Fall of the Western Parts (Roman Imperial Coinage) 10 (London, 1994), pp. 70-73. pp. 7-9 and Fergus Millar A Greek Roman Empire: Power and Belief under Theodosius II 408-45o (Berkeley, 2006), p. 58. 

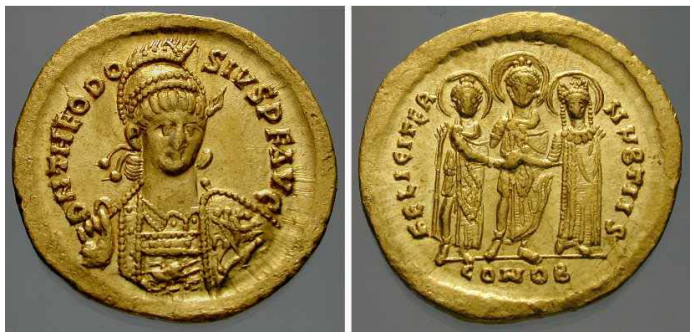

FIGURE 6.4

FELICITER NUPTIIS festal solidus struck at Constantinople for the wedding of Valentinian III and Eudoxia in 437. The solidus features a portrait of Theodosius II, the senior emperor, who is shown embracing the bride and groom. With this gesture, he embodies the oneness of the empire, the future of which the wedding, as an act of concordia augustorum was meant to ensure. PHOTO () CLASSICAL NUMISMATIC GROUP, INC, HTTP://WWW.CNGCOINS.COM.
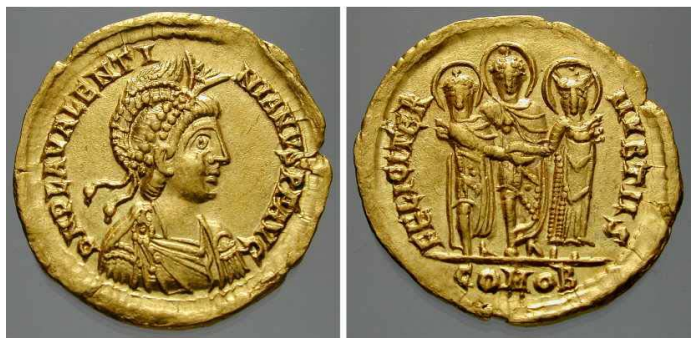

FIGURE 6.5

FELICITER NUPTIIS festal solidus struck at Thessalonica for the wedding of Valentinian III and Eudoxia in 437. The solidus features a portrait of Valentinian III, appointed Caesar in 424 at the age of five, when he was engaged to Licinius Eudoxia, who was barely three years old. PHOTO () CLASSICAL NUMISMATIC GROUP, INC, HTTP://WWW.CNGCOINS.COM.

In these years, Rome was again an imperial residence. The young imperial couple alternated between their palaces at Rome and Ravenna, where Licinia Eudoxia was proclaimed Augusta on 6 August 439. She also spent several months in Rome, where Valentinian joined her from 24 January to 20 March $440 .{ }^{26}$ An inscription found in an aristocratic dwelling near the Lateran, dedicated to Eudoxia and Valentinian by the Roman nobleman Flavius Florinus, of whom there are otherwise no records, could reflect her stay in the city.

\author{
Dominae nostrae \\ Eudoxiae Augustae \\ Coniugi d(omini) n(ostri) Placidi
}

26 For the proclamation of Eudoxia as Augusta after the birth of their first child, Eudocia, see Liber Pontificalis Ecclesiae Ravennatis 31: "et facta est domna Eudoxia Augusta Ravennae viII idus Augusti” and Chronica Gallica 511 s.a.: "Eudoxia Ravenna regnum accepit" (Monumenta Germania Historica Auctorum Antiquissimorum, Chronica Minora ed. Theodor Mommsen (Berlin, 1892, 1961) I, p. 523; PLRE 2, pp. 410-12 "Eudoxia 2"). See also Andrew Gillett, "Rome, Ravenna, and the last emperors," Papers of the British School at Rome 69 (2001), p. 143 and Julia Burman, "The Athenian Empress Eudocia," in Post-Herulian Athens, ed. Paavo Castrén (Helsinki, 1994), p. 85. 


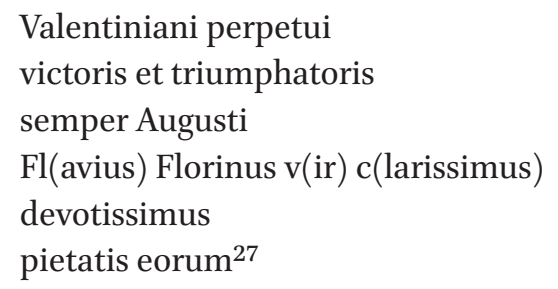

Certainly, the devotion that the young empress and emperor inspired among some members of Rome's elite circles, can be felt.

The couple also seems to have been instrumental in transplanting Roman devotion to Peter and Paul in fertile soil in their other capital, Ravenna. The evidence strongly suggests that Valentinian and Licinia Eudoxia were responsible for dedicating a church to Peter and Paul, Ecclesia Apostolorum (today's S. Francesco), at Ravenna during the late $430{ }^{28}{ }^{28}$ Indeed, these two sister churches at Rome and Ravenna seem to express close co-operation between the church and the imperial house as well as the special importance that members of the Theodosian dynasty attached to the cult of Sts. Peter and Paul during the 430 s and $440 \mathrm{os}$. Did the dynasty complete this patronal programme by erecting a church to Peter and Paul in Constantinople? Certainly, in the concord of the apostles, concordia apostolorum, they seem to have seen a reflection of the desired concord of the eastern and western branches of their imperial house, concordia augustorum.

\section{The Church of Sts Peter and Paul in the Triconch at Constantinople}

Before the reign of Theodosius II, it seems, there was no church dedicated exclusively to Peter and Paul within the walls of Constantinople. Yet according to Theophanes, an early ninth-century chronicler, a church dedicated to The Holy Apostles Peter and Paul in the Triconch burnt down during the reign of Zeno,

27 During the excavation a fresco and a hoard of coins (now missing) were found. Although it remains uncertain, Scrinari has suggested that the couple depicted on the fresco is Eudoxia and Valentinian III. See Valnea Santa Maria Scrinari, Horti Domitiae, Monumenti di antichità Cristiana (The Vatican City, 1991-1997), pp. 261-262. See also Valnea Santa Maria Scrinari, "Contributo all'urbanistica tardo antica sul campo Laterano," Actes du XIe Congrès international d'archéologie chrétienne, 3 (Rome, 1989), p. 2213; Paolo Liverani, "L'area lateranense in età tardoantica e le origini del patriarchio," Mélanges de l'École Française 116.1 (Rome, 2004) 17-49.

28 Friedrich W. Deichmann, Ravenna: Hauptstadt des Spätantiken Abendlandes, 2 (Wiesbaden, 1976-), pp. 308-318. 
emperor from 474 to 491 (with a break from 475 to 476 ). ${ }^{29}$ This fire probably broke out during the series of earthquakes that struck the capital from September 24, 479 - some fifty years before Justinian inaugurated the church to Peter and Paul, which Procopius claimed was Constantinople's first of its kind. Liturgical texts confirm that an annual commemoration ceremony took place in the church in the Triconch on November $6 .{ }^{30}$ The date is confirmed by the witness of such sixth-century historians as John Malalas, Marcellinus Comes, Theodor Lector and Procopius, according to whom every year on November 6 the citizens of Constantinople remembered the fearful eruption of Mount Vesuvius in $472 .{ }^{31}$ This had caused ashes, blown with wind from Italy, to fall as burning rain over Constantinople. The scene was later vividly depicted in an illustration from the Menologion of Basil II (976-1025): burning ash falls from heaven, while people seek protection and refuge in a church. There is good reason to suggest that the building in the miniature represents The Holy Apostles Peter and Paul in the Triconch rebuilt by Justin II, in which the commemoration of the fall of the dust took place during the medieval period. ${ }^{32}$

If the annual commemoration of this event at the church in the Triconch reflects the original flight of the people of Constantinople to it, seeking the protection of Peter and Paul at the time of Vesuvius' eruption, it recalls the actions of Chrysostom's congregation following the terrible storm of 399. Either way, if we can trust the sources, the church in the Triconch must have been

29 The Chronicle of Theophanes AM 6o64, ed. Carolus de Boor (Leipzig, 1883), p. 244. See also Cyril Mango \& Roger Scott, The Chronicle of Theophanes Confessor (Oxford, 1997), p. 361. A reconstruction of the church was undertaken by Justin I in $571-572$, as noted in the same passage.

See the Synaxarium and the Typicon, a ninth- and a tenth-century calendar, based on older archives: Hippolyte Delehaye ed., Synaxarium Ecclesiae Constantinopolitanae (Brussels, 1902), p. 198, Synaxaria Selecta H: 1.2. add: \& P: 1.2 and 882; Juan Mateos ed., Le Typicon de la Grande Église. Ms. Sainte-Croix no 40, X siècle. Introduction, commentary and translation, Orientalia Christiana Analecta, 1 (Rome, 1962), pp. 90-93. For the location, see also Mango and Scott, The Chronicle of Theophanes Confessor, p. 362. According to the Typikon, the synaxis took place in 'Sts. Peter and Paul in the Triconch', where a morning procession went from the Great Church to the Forum. After the usual prayers, the procession went to the aforementioned synaxis. The patriarch said the Gloria Patri in the Forum as well as in the Triconch.

The Chronicle of Marcellinus Comes in the year 472, ed. Croke, p. 115. The Chronicle of John Malalas 14.372.42 ed. Dindorf (Bonn, 1831), p. 372; Theodor Lector, Historia Ecclesiastica 398, ed. Günther Christian Hansen (Berlin, 1995), p. 111; Procopius, The History of the Wars 6.4.27, ed. Henry Bronson Dewing (Cambridge Mass., 1960), p. 327. 
built before 472, in order to house the ceremony commemorating the fall of the ash occurring in that year. The year 472 is thus a terminus ante quem for its construction. ${ }^{33}$ For a terminus post quem, we can note that the church in the Triconch is not mentioned in the Notitia urbis Constantinopolitanae, a list of buildings at Constantinople from 425. The Holy Apostles Peter and Paul in the Triconch must, therefore, have been built between 425 and 472 , that is to say while a Theodosian sat on the throne. ${ }^{34}$

Although it remains uncertain who the patron of this church was, given the Theodosian building program and the other circumstantial evidence, it seems likely that he or she was a member of the Theodosian house. Indeed, it is plausible that, like the Ecclesia Apostolorum at Ravenna, the Holy Apostles Peter and Paul in the Triconch at Constantinople was built as a sister church to the titulus Apostolorum in Rome. As such it would have been one in a range of gestures of imperial unity, concordia augustorum, the eastern and western branches of the Theodosian House exchanged during the 430s, a unity of which the concordia of the apostles functioned as a symbol.

The very location of the church in the Triconch seems to suggest that an ideology of concord inspired its construction. The church was prestigiously located near Constantinople's Capitolium and the Philadelphion palace, an important nodal point for processions through the city (map 6.1) ${ }^{35}$ Crucially, the toponym Philadelphion, which means 'brotherly love', derived from the famous representation of imperial unity flanking the entrance to the Philadelphion Palace, that of the embracing Tetrarchs (now at Venice). ${ }^{36}$ Indeed, in a city

33 Janin dates the church in the Triconch to the late fourth century, but the date seems implausible, as Chrysostom does not pay a visit during the celebration of the feast of Peter and Paul. See Raymond Janin, La géographie ecclésiastique de l'Empire byzantin, Les églises et les monastères, 3 (Paris, 1953, 1969), p. 401.

34 The Emperor Anthemius (467-472) was a Theodosian in as much as he married Marcian's (450-457) daughter, Marcia Euphemia: Marcian was married to Pulcheria, Theodosius I's sister.

35 For the location of the Triconch near the Capitolium, see the Synaxarium Ecclesiae Constantinopolitanae 882.1 and Cyril Mango and Roger Scott, The Chronicle of Theophanes Confessor, p. 362. See also Cyril Mango Le développement urbain de Constantinople IVe-VIIe siècles (Paris, 1985), p. 28-30; Franz Alto Bauer, "Urban Space and Ritual: Constantinople in Late Antiquity," in Imperial Art as Christian Art - Christian Art as Imperial Art: Expression and meaning in art and architecture from Constantine to Justinian, Acta ad Archaeologiam et Artium Historiam Pertinentia 15, eds. Rasmus Brandt and O. Steen (Rome, 2001), p. 30 .

36 Franz Alto Bauer, "Urban Space and Ritual", p. 31; Franz Alto Bauer, Stadt, Platz und Denkmal in der Spätantike: Untersuchungen zur Ausstattung des öffentlichen Raums in den spätantiken Städten Rom, Konstantinopel und Ephesos (Mainz am Rhein, 1996), p. 228. 

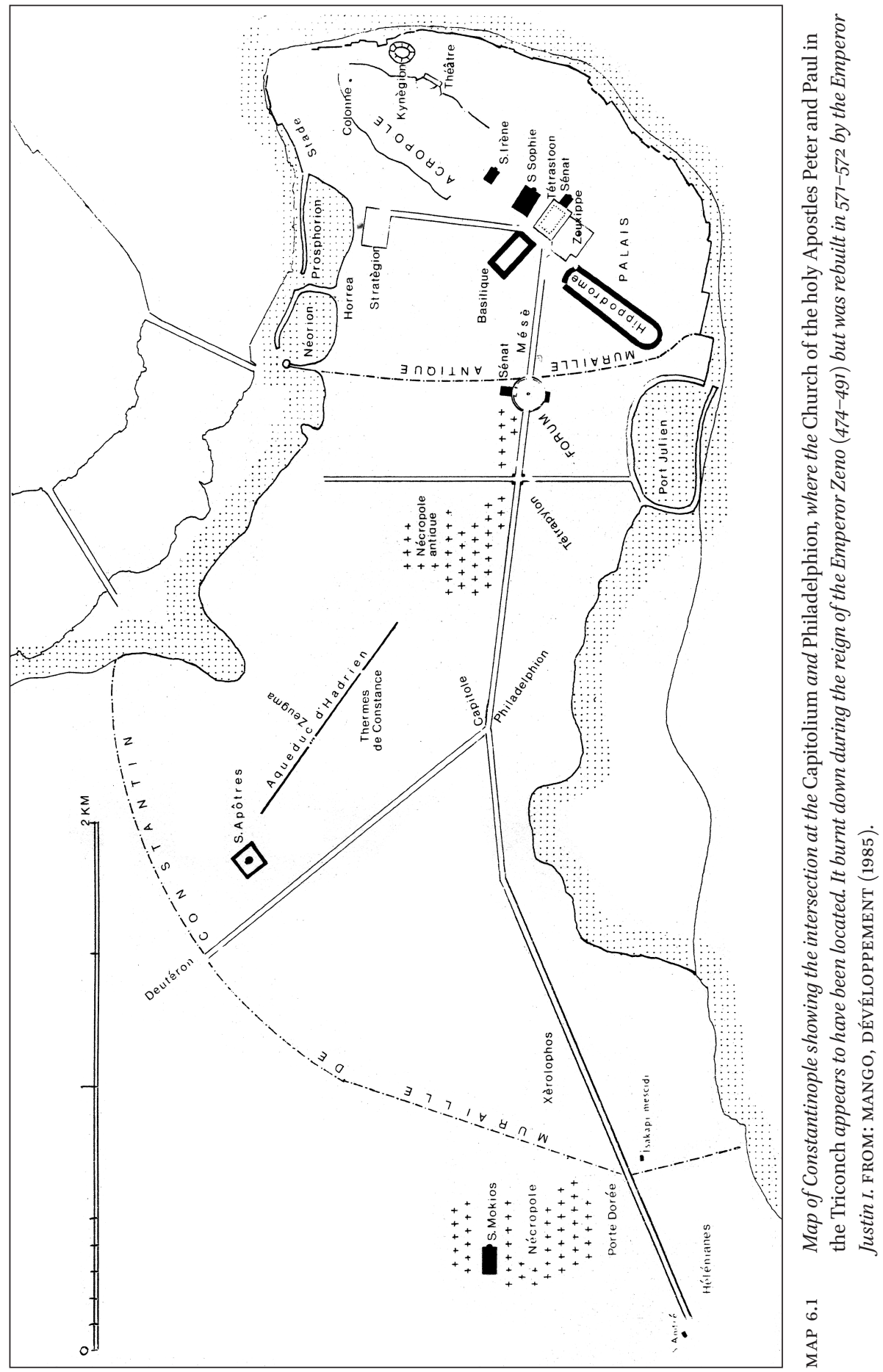
where sacred sites directly associated with the apostles Peter and Paul were absent and had to be created ex novo (as opposed to the prestigious tombs at Rome) what would have been more appropriate in the light of the Theodosian endeavours at Rome, than to erect a church to the pair of apostles, emblems of concordia apostolorum and concordia fratrum i.e. 'brotherly love', at this crossroad invested with symbols of concordia augustorum and $\varphi 1 \lambda \alpha \delta \dot{\varepsilon} \lambda \varphi \varepsilon 1 \alpha$ ? ${ }^{37}$

Moreover, in this neighbourhood of the Philadelphion, Theodosius' daughter Licinia Eudoxia later erected another family church. As recently suggested by Kim Bowes, this church served to enhance the connection between the Theodosian family and the Church. ${ }^{38}$ This is also likely to have been part of the intention behind the churches dedicated to Peter and Paul by these imperial patrons in their three residential cities Rome, Constantinople and Ravenna: i.e. to enhance and embody their Christian romanitas and the unity of church and empire at a time when (in the face of heretics within and invading barbarians from without) such unity was especially desirable. By merging the ideologies of concordia apostolorum and concordia augustorum, the Theodosian House would have shaped their "corporate image" in continuity with both traditional Roman and more novel Christian values, moulding the notions of concordia and romanitas to their own purposes. This corporate image proclaimed the Theodosians as pious Roman emperors of a unified Christian Empire, and would have helped ensure that they were remembered as such by future generations. This dynastic memory of unity was materialised in laws and edicts, coins and wedding ceremonies, images, inscriptions and buildings: "Theodosius I followed the Dynastic Principle, by making it clear throughout that the integrity of the Empire depended upon himself and his family, including its women. The architecture, patched together laboriously from often discordant elements, nonetheless displayed a unifying theme." 39

A significant target group for such a carefully constructed and mediated corporate image must have been Constantinople's very cosmopolitan elite, made up as it was by newly created senators, praetors, officiales, comites and more from across the eastern empire. Theodosius I faced the local challenge of unit-

37 On concordia fratrum, see Herbert L. Kessler, "The Meeting of Peter and Paul in Rome: An Emblematic Narrative of Spiritual Brotherhood," Dumbarton Oaks Papers 41 (1987) 267268 .

38 Kim Bowes, Private Worship, Public Values, and Religious Change in Late Antiquity (New York, 2008), pp. 107-109. The church Haghia Euphemia en tois Olybriou was dedicated and cared for by Eudoxia's daughter Placidia, her husband Olybrius and later by their daughter, Anicia Juliana.

39 Kenneth Holum, Theodosian Empresses. Women and Imperial Dominion in Late Antiquity (Berkeley, 1982), p. 7 . 
ing not only religious schismatics (i.e. Arians) in much the same way as Damasus did, but also the composite elite consisting of ambitious individuals from diverse social and cultural backgrounds. And like Damasus, Theodosius took a series of measures to create common grounds among the elite groups of his new capital. As noted by Inglebert, the fifth century was a period of "unification mentale, au moins telle qu'elle fut vécue par ses élites, mais aussi concrète" (p. 24 in this volume).

One way of encouraging a sense of unity and community among these groups was enforcing uniformity. As recently and persuasively treated by Errington, Theodosius issued regulations on public appearance imposing, for instance, the traditional Roman dress code of toga and paenula. ${ }^{40}$ The fine for failing to exhibit oneself in traditional Roman attire was up to 20 pounds of gold. Senators risked exclusion from the assembly, while government officials risked exile from the city! According to Errington,

The existence of an adequate socioeconomic elite was essential for a ruling city in the empire [Constantinople], and the creation of an effective senatorial class in the East, together with its focus on the new city of Constantinople, turned out to be a major factor in binding the eastern landowning classes into the imperial governmental structure and creating vested political and economic interests in its continuation. ${ }^{41}$

From this perspective, it seems fitting that Theodosius I and his co-emperors should have promoted the cult of the founders and patron saints of the Roman Church, Peter and Paul, investing in significant building projects at Rome to regulate the spaces of Christian worship and its front figures. Like the dress code and public building programme, which closely followed Roman models, the cult of Peter and Paul can be seen as part of the package of things 'Roman' that continued to be imported to Constantinople under Theodosius I. While he sought to emphasise the unity of church and empire, his grandson Theodosius II expanded the use of the traditional Roman value, virtue and ideology of concordia to unite the two halves of the dynasty itself at a time when Christian and Roman had become far less distant categories. Materialised in churches to Peter and Paul in their three residential cities, concordia stood at the very core of the dynastic memory, which the Theodosian dynasty was building for future generations.

40 Codex Theodosianus 15.1.25 and 14.10.01. See Malcolm Errington, Roman Imperial Policy, pp. 165-167.

41 Malcolm Errington, Roman Imperial Policy, pp. 146-147. 


\section{Concluding Remarks}

In light of Hervé Inglebert's study, this article has explored the combination of political, religious and cultural aspects, which shaped and reinforced the relationship between the eastern and western parts of the empire. The three themes of unicité, unité and unification emerged in various ways: Theodosius II's appointment and legitimisation of Valentinian III reflects the political dimension of unicité or oneness and inseparability of the imperium, while the ideology of concordia reflects the rhetorical dimension. To be sure, the rhetorical dimension of concordia was not only linguistic: the written legends on the coinage were accompanied by the widespread iconographical templates of emperors - and apostles - embracing, shaking hands or looking at each other.

The theme of unité with its connotations of community and connectedness has come up in relation to the Theodosian House providing several emperors and empresses to the eastern and western courts and minting solidi to mark their commitment to each other, such as the wedding in 437. The act of marriage and the Theodosian Code, published during this event, also represent juridical aspects of unité. As pointed out by Inglebert: "Théodose II ne pensait pas différemment en donnant un empereur de sa famille à l'Occident en 423 en la personne de Valentinien III et en faisant promulguer son Code à Rome et à Constantinople en 438 , réaffirmant ainsi l'unité dynastique et juridique d'un monde romain que l'on ne pouvait pas penser pluriel (p. 23)."

There also seems to have been a juridical aspect of the cult of Peter and Paul: in a law issued in Constantinople on February 1, 425, Theodosius II and Valentinian III decreed that "the commemoration of the apostolic passion" (et commemoratio apostolicae passionis) must be "duly celebrated by everyone [...]." As I have discussed elsewhere, the commemoration almost certainly refers to the joint martyrdom of Peter and Paul, which, seems to have been recognized as one of the Christian feasts binding the, now, Christian empire together. ${ }^{42}$

Inglebert's third theme, unification, addresses religious and cultural mentality (among other things) based on a set of shared Roman values. This is crucial to the present study in as much as the cult of Peter and Paul concerns precisely that: exporting the Roman cult to Constantinople was closely related to the idea or mentality of romanitas or Roman-ness - that is, being Roman. As Inglebert emphasises, unification depends on manifestations of unicité and unite. Indeed, the religious and cultural mentality relating to Sts. Peter and Paul, the cult and its ideology of concordia was linked to the diffusion of the imperial

42 For a more detailed discussion, see Gitte Lønstrup Dal Santo, "Bishop and Believers", pp. $244-247$. 
ideology of concordia (unicité) and the support of the Theodosian House across the empire (unité). While Inglebert's conceptual distinction may have little effect on the outcome of this article, it certainly responds to the discourse that outlined in his study.

To conclude, it would be appropriate to return to Procopius with whom this article began. We know from such sixth-century historians as Malalas, Evagrius and Agathias that Procopius was read by his contemporaries and that parts of the Buildings may have been read at the court. ${ }^{43}$ Like any panegyric, it was designed to maximize the achievements of the ruler and exaggeration and manipulation of facts are fundamental to this genre. Yet much existing scholarship has taken Procopius' text at face value. This is doubtless why the pre-Justinianic cult and churches of the apostles Peter and Paul in Constantinople have been neglected.

For this reason, this re-reading of Procopius has focused less on the impact of his work on his contemporaries. Its focus has instead been its longterm impact on the scholarship on the churches of Peter and Paul in Constantinople. This is crucial, because scholars often use Procopius' panegyric as a catalogue or a checklist, providing factual information on the buildings commissioned by Justinian. ${ }^{44}$ But this article has countered Procopius' claim that Justinian was the first patron of a church to Peter and Paul in Constantinople by demonstrating that the Constantinopolitan cult and churches of these apostles had been key to Theodosian patronage and dynastic memory-making before the time of Justinian. Rather than being original, Justinian's patronage was a continuation of that pursued by his Theodosian predecessors. And like the Theodosian churches erected to Peter and Paul, Justinian's church was an embodiment of the concordia established between the bishop of Rome in the west and the Constantinopolitan court in the east to put an end to the twentyyear-long Acacian schism (484-518/19). The term concordia emerges explicitly from the correspondence regarding the transfer of relics of Peter and Paul from Rome needed for the inauguration of Justinian's church at Constantinople. ${ }^{45}$

43 Warren T. Treadgold, The Early Byzantine Historians (London, 2007), p. 227. Treadgold notes that Procopius' heirs might have arranged for the distribution of Buildings that would have interested the reading public and gratified the emperor.

44 Jaś Elsner, "The Rhetoric of Buildings in the de Aedeficiis of Procopius," in Art and text in Byzantine culture, ed. Liz James (Cambridge, Eng., 2007), p. 45: "modern scholarship has effectively missed the rhetorical point that Procopius' Buildings are not factual descriptions but literary ciphers for much more than accuracy could ever afford".

Concordia is referred to in several of the correspondences between the Constantinopolitan court and the Roman church. See Corpus Scriptorum Ecclesiasticorum Latinorum 35, 2, pp. 143, 144, 147, 148, 191, 217. 
Once again Peter and Paul were called upon as emblems of unity between church and empire, and between the old Rome on the Tiber and the New Rome on the Bosporus. Nonetheless, their pre-Justinianic cult and churches in Constantinople have not been widely acknowledged - and for the most part the cult and the ideology of concord have been limited to Rome. However, the commemoration of the Roman festival of June 29, 399 and the annual commemoration of the fall of the ash at The Holy Apostles Peter and Paul in the Triconch are compelling evidence for the importation of the cult of Peter and Paul at Constantinople and with it, its inherited connotation of concordia - no longer as a separate Christian counterpart of imperial ideology, but now merged with it. At a time when division may have been the easy choice, a commitment to religious and imperial unity, Concordia Apostolorum and Concordia Augustorum was at the forefront of Theodosian politics.

\section{Bibliography}

Franz Alto Bauer, Stadt, Platz und Denkmal in der Spätantike: Untersuchungen zur Ausstattung des öffentlichen Raums in den spätantiken Städten Rom, Konstantinopel und Ephesos (Mainz am Rhein, 1996).

—_ "Urban Space and Ritual: Constantinople in Late Antiquity," in Imperial Art as Christian Art - Christian Art as Imperial Art: Expression and meaning in art and architecture from Constantine to Justinian, eds. Rasmus Brandt and O. Steen, Acta ad Archaeologiam et Artium Historiam Pertinentia 15 (Rome 2001), pp. 27-61.

Nathanael Andrade, "The Processions of John Chrysostom and the Contested Spaces of Constantinople," Journal of Early Christian Studies, 18.2 (2010), 161-189.

Joseph Bidez, Sozomen, Kirchengeschichte (Die griechischen christlichen Schriftsteller) (Berlin, 1960).

Kim Bowes, Private Worship, Public Values, and Religious Change in Late Antiquity (New York, 2008).

Julia Burman, "The Athenian Empress Eudocia," in Post-Herulian Athens, ed. Paavo Castrén (Helsinki, 1994), pp. 63-87.

Averil Cameron, Procopius and the sixth century (London, 1985).

Brian Croke, The Chronicle of Marcellinus Comes, Australian Association for Byzantine Studies (Sydney, 1995).

John Curran, Pagan city and Christian capital: Rome in the fourth century (New York, 2000).

Carolus de Boor, Theophanis chronographia (Leipzig, 1883).

Friedrich W. Deichmann, Ravenna:Hauptstadtdes Spätantiken Abendlandes (Wiesbaden, 1976). 
Hippolyte Delehaye ed., Synaxarium Ecclesiae Constantinopolitanae (Brussels, 1902)

Giovanni Battista De Rossi, Inscriptiones Christianae Urbis Romae septimo saecula antiquores (Rome, 1857-1915).

Henry Bronson Dewing, Procopius. Buildings (Cambridge, Mass., 1940, 2002).

—, The History of the Wars (Cambridge, Mass., 1960).

Ludwig Dindorf, Ioannis Malalae chronographia (Corpus scriptorum historiae Byzantinae) (Bonn, 1831).

Marina Docci, San Paolo fuori le mura: dalle origini alla basilica delle "origini” (Rome, 2006).

Jaś Elsner, "The Rhetoric of Buildings in the de Aedeficiis of Procopius," in Art and text in Byzantine culture, ed. Liz James (Cambridge, Eng., 2007), pp. 33-57.

Malcolm Errington, Roman Imperial Policy from Julian to Theodosius (Chapel Hill, 2006). Antonio Ferrua, Epigrammata Damasiana (The Vatican City, 1942).

—, "Rileggendo i graffiti di San Sebastiano", Civiltà Cattolica 3 (1956) 428-437 and 4, pp. 134-141.

Giorgio Filippi, "La Basilica di San Paolo fuori le mura," in Pietro e Paolo. La storia, il culto, la memoria nei primi secoli, ed. Angela Donati (Milan, 2000), pp. 59-62.

Andrew Gillett, "Rome, Ravenna, and the last emperors", Papers of the British School at Rome 69 (2001) 131-67.

Günther Christian Hansen, Theodoreos Anagnostes Kirchengeschichte (Die griechischen christlichen Schriftsteller) (Berlin, 1995).

—, Kirchengeschichte Sokrates (die griechischen christlichen Schriftsteller) (Berlin, 1995).

Kenneth Holum, Theodosian Empresses. Women and Imperial Dominion in Late Antiquity (Berkeley, 1982).

John M. Huskinson, Concordia Apostolorum: Christian Propaganda at Rome in the Fourth and Fifth Centuries: A Study in Early Christian Iconography and Iconology, BAR International Series (Oxford, 1982).

Il Menologio di Basilio II, Cod. Vaticano Greco 1613, Codices e Vaticanis selecti 8, 1-2 (Turin, 1907).

Raymond Janin, La géographie ecclésiastique de l'Empire byzantin, Les églises et les monastères 3 (Paris, 1953, 1969).

A.H.M. Jones, J.R. Martindale and J. Morris, eds., The prosopography of the later Roman Empire (Cambridge, Eng., 1971-).

Walter E Kaegi, Byzantium and the decline of Rome (Princeton, 1968).

John P.C. Kent, The Divided Empire and the Fall of the Western Parts, Roman Imperial Coinage 10 (London, 1994).

Herbert L. Kessler, "The Meeting of Peter and Paul in Rome: An Emblematic Narrative of Spiritual Brotherhood," Dumbarton Oaks Papers, 41 (1987) 265-275. 
Richard Krautheimer, Corpus Basilicarum Christianorum Romae, 3 (The Vatican City, 1937-1977).

Hans Lietzmann, Die drei ältesten Martyrologien (Bonn, 1911).

Paolo Liverani, "L'area lateranense in età tardoantica e le origini del patriarchio," Mélanges de l'École Française de Rome 116.1 (2004) 17-49.

Gitte Lønstrup Dal Santo, "Bishop and Believers - Patrons and Viewers: Appropriating the Roman Patrons Saints Peter and Paul in Constantinople," in Patrons and Viewers in Late Antiquity, eds. Stine Birk and Birte Poulsen (Aarhus, 2012), pp. 237-257.

Cyril Mango, Le développement urbain de Constantinople IVe-VIIe siècles (Paris, 1985).

Cyril Mango and Roger Scott, The Chronicle of Theophanes Confessor (Oxford, 1997).

Juan Mateos ed., Le Typicon de la Grande Église. Ms. Sainte-Croix no 4o, X siècle.

Introduction, commentary and translation, Orientalia Christiana Analecta (Rome, 1962).

John F. Matthews, Western Aristocracies and Imperial Court A.D. 364-425 (Oxford, 1990). , Laying Down the Law: A Study of the Theodosian Code (New Haven, 2000).

Wendy Mayer and Pauline Allen, John Chrysostom, The Early Church Fathers (London, 2000).

Fergus Millar, A Greek Roman Empire: Power and Belief under Theodosius II 408-450 (Berkeley, 2006).

Theodor Mommsen ed., Monumenta Germania Historica Auctorum Antiquissimorum, Chonica Minora (Berlin, 1892, 1961).

Jean Pargoire, "Rufinianes," Byzantinische Zeitschrift 8 (1899) 433-437.

- "Les homélies de S. Jean Chrysostome en juillet 399", Echos d'Orient 2 (1900), 151-162.

Charles Pietri, "Concordia Apostolorum et Renovatio Urbis. Culte des martyrs et propagande pontificale," Mélanges de l'Ecole française de Rome. Antiquité 73 (1961), $275-322$.

— Roma christiana: Recherches sur l'église de Rome, son organisation, sa politique, son idéologie de Miltiade à Sixte III 311-440 (Rome, 1976).

Peter Sarris, The Secret History (London, 2007).

Valnea Santa Maria Scrinari, Horti Domitiae (Monumenti di antichità Cristiana) (The Vatican City, 1991-1997).

—_ "Contributo all'urbanistica tardo antica sul campo Laterano," Actes du XIe Congrès international d'archéologie chrétienne, 3 (Rome, 1989), pp. 2201-2220.

Margarete Steinby ed., Lexicon Topographicum Urbis Romae (Rome, 1993-2000).

Alan Thacker "Rome of the martyrs: Saints, Cults and Relics, Fourth to Seventh centuries," in Roma Felix - Formation and Reflections of Medieval Rome, eds. Éamonn Ó Carragáin and Carol Neuman de Vegvar (Aldershot, 2007), pp. 13-50. 
Dennis E. Trout, "Damasus and the Invention of Early Christian Rome," Journal of Medieval and Early Modern Studies 33 (2003), pp. 517-536.

Warren T. Treadgold, The Early Byzantine Historians (London, 2007).

Bryan Ward-Perkins, From Classical Antiquity to the Middle Ages. Urban Public Building in Northern and Central Italy AD 300-850 (Oxford, 1984). 